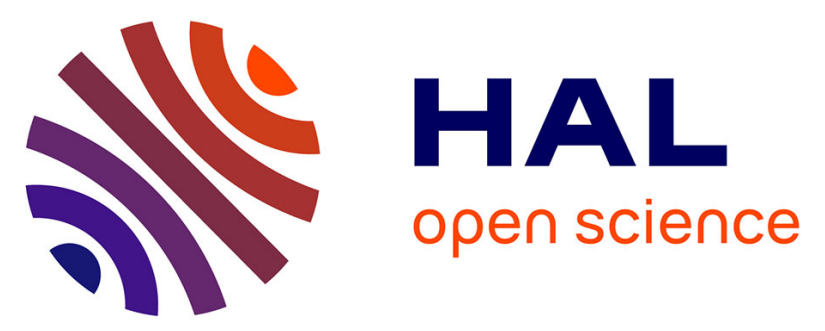

\title{
Extracorporeal membrane oxygenation for immunocompromised children with acute respiratory distress syndrome: a French referral center cohort
}

Blandine Robert, Isabelle Guellec, Julien Jegard, Sandrine Jean, Julia

Guilbert, Yohan Soreze, Julie Starck, Jean-Eudes Piloquet, Pierre-Louis Leger, Jérôme Rambaud

\section{To cite this version:}

Blandine Robert, Isabelle Guellec, Julien Jegard, Sandrine Jean, Julia Guilbert, et al.. Extracorporeal membrane oxygenation for immunocompromised children with acute respiratory distress syndrome: a French referral center cohort. Minerva Pediatrica, 2020, Online ahead of print. 10.23736/S00264946.20.05725-4 . inserm-03285228

\section{HAL Id: inserm-03285228 https://www.hal.inserm.fr/inserm-03285228}

Submitted on 13 Jul 2021

HAL is a multi-disciplinary open access archive for the deposit and dissemination of scientific research documents, whether they are published or not. The documents may come from teaching and research institutions in France or abroad, or from public or private research centers.
L'archive ouverte pluridisciplinaire HAL, est destinée au dépôt et à la diffusion de documents scientifiques de niveau recherche, publiés ou non, émanant des établissements d'enseignement et de recherche français ou étrangers, des laboratoires publics ou privés. 
Extracorporeal membrane oxygenation for immunocompromised children with acute respiratory distress syndrome: a French referral center cohort

Blandine ROBERT ${ }^{1}$, Isabelle GUELLEC ${ }^{1}$, Julien JEGARD ${ }^{1}$, Sandrine JEAN ${ }^{1}$, Julia

GUILBERT $^{1}$, Yohan SOREZE ${ }^{1}$, Julie STARCK ${ }^{1}$, Jean-Eudes PILOQUET ${ }^{1}$, Pierre-Louis LEGER $^{1}$, Jerome RAMBAUD ${ }^{1 *}$.

1: Pediatric and neonatal intensive care unit, Armand-Trousseau hospital, Sorbonne University, Paris, France.

Key words : ARDS, immunocompromised, children, veno-venous ECMO, veno-arterial ECMO

Corresponding authors:

Rambaud Jérôme jerome.rambaud@aphp.fr

Pediatric and neonatal intensive care unit, Armand-Trousseau hospital 26 avenue du Dr Arnold Netter, Sorbonne University, Paris, France 


\begin{abstract}
Background: Immunocompromised children are likely to develop a refractory acute respiratory distress syndrome (ARDS). The usefulness of providing extracorporeal life support (ECLS) to these patients is a subject of debate. The aim of our study was to report the outcomes and to compare factors associated with mortality between immunocompromised and non-immunocompromised children supported with veno-venous ECMO.
\end{abstract}

Methods: We performed a retrospective monocentric study in the French pediatric ECMO center of Armand Trousseau Hospital, including all pediatric patients aged from 1 month to 18 years requiring ECLS for ARDS.

Results: Between 2007 and 2018, one hundred and eleven (111) patients underwent ECMO for respiratory failure; among them twenty-five (25) were immunocompromised. Survival rate at 6 months after intensive care discharge was significantly lower for immunocompromised patients compared to non-immunocompromised ones $(41.7 \%$ vs. $62.8 \%$; $p=0.04)$. ARDS severity was similar between the 2 groups. Fungal pneumonias were reported only in immunocompromised patients $(12.5 \%$ versus $0 \%$ in the control group; $\mathrm{p}=0.001)$. Bleeding complications were significantly more frequent in the immunocompromised group and blood product transfusions were also more frequently required in this group.

Conclusion: Six months after intensive care discharge, survival rate of immunocompromised children supported with ECMO for pediatric ARDS is lower than for nonimmunocompromised patients. But, the expectation for a favorable outcome is real and it is worth it if their condition is likely to be compatible with a good long-term quality of life. 


\section{INTRODUCTION}

Acute respiratory distress syndrome (ARDS) is a life-threatening condition associated with significant morbidity and mortality in children ${ }^{(1,2)}$. In 2015 , the Pediatric Acute Lung Injury Consensus Conference (PALICC) expert group has specifically defined pediatric ARDS (P-ARDS) so as to offer recommendations regarding therapeutic support, including consideration of Extracorporeal Life Support (ECLS) ${ }^{(3)}$. Overall survival has been stable around $60 \%$ of the time over the last 25 years in pediatric patients supported with respiratory ECLS. However, there is a sharp increase of associated comorbidities, including immune compromise conditions ${ }^{(4,5)}$. Immunocompromised children are likely to develop infections and pulmonary complications due to their underlying condition or secondary to the immunosuppressive treatments ${ }^{(6,7)}$. Thus, they can suffer from acute hypoxemic respiratory failure. It has been previously reported that clinically significant immunodeficiency is associated with an increased risk of death in patients with ARDS ${ }^{(2,8-11)}$. Before 2000, immunodeficiency was considered as a potential contraindication for ECMO. However, in the last decade, more and more patients benefited from ECMO with controversial results. A recent study of 203 immunocompromised adults with ARDS and undergoing ECMO reported a survival rate of $30 \%{ }^{(12)}$ re-opening the debate concerning the usefulness of this treatment in this specific population ${ }^{(13)}$.

Although the negative effect of preexisting immunodeficiency on the survival of PARDS patients has been already established, factors associated with mortality, including ECMO-related complications, have not been properly investigated so far.

Our study hypothesis is that survival rate of immunocompromised patient undergoing ECMO for ARDS is increasing. Our aims were first, to report outcomes of immunocompromised children supported with ECMO for P-ARDS and second, to identify 
risk factors associated with mortality, before and during ECMO runs, including ECMOrelated complications; compared with non-immunocompromised children.

\section{METHODS}

We performed a retrospective monocentric study from January 2007 to December 2018 in the ECMO reference center of Armand-Trousseau Hospital, Paris, France.

All pediatric patients aged from 1 month to 18 years old and requiring extracorporeal membrane oxygenation for refractory acute respiratory distress syndrome were included. Immunocompromised children were defined as having solid tumor under chemotherapy, solid-organ transplantation, bone marrow transplantation, hematological malignancy or congenital immunodeficiency syndrome.

Exclusion criteria were missing data or parental opposition.

\section{Data collection:}

Data collected were age, gender, weight, ARDS etiology and severity score (PIM II ${ }^{(14)}$ and PELOD score ${ }^{(15)}$, vasoactive-inotropic score $\left.{ }^{(16)}\right)$, oxygenation features $\left(\mathrm{PaO}_{2} / \mathrm{FiO}_{2}\right.$ ratio, oxygenation index and the oxygenation saturation index) lab characteristics $\left(\mathrm{PaCO}_{2}, \mathrm{pH}\right.$, lactate, white blood cells, neutrophils, lymphocytes and platelets count). We looked for preECMO previous treatment such as mechanical ventilation settings (plateau pressure, positive end expiratory pressure, driving pressure, mean pressure, inspiratory pressure), the use of prone positioning, nitric oxide, exogenous surfactant, neuromuscular blockers and high frequency oscillation. We also gathered ECMO-related complications (massive hemorrhage, brain death or stroke, ventilator acquired pneumonia and central line associated bloodstream infection, fluid overload and need for renal replacement therapy), the need for blood and 
blood product transfusions. We collected outcome criteria as the median duration of ECMO, the length of invasive mechanical ventilation, the length of intensive care stay and the survival rate following intensive care (ICU) discharge and 6 months after ICU discharge.

\section{Statistics:}

Data analyses were performed using Stata version 13.0 (Stata Corp, College Station, TX). Categorical variables were expressed in percentage and compared using Fischer exacttest. Kolgomorov analysis was performed to test the normal distribution of our continuous variables. Continuous variables were normally expressed as median and range and compared with Mann-Whitney test. For non-normally distribute variables, Kruskall Wallis for nonparametric datas was used. $P<0.05$ was considered significant. Chi square test was used to assess the significance of the difference between percent rates.

The study was approved by the Ethic Committee of our institution as an observational study and the computerized data collection was approved by the French Data Protection Authority (n²121127V0).

\section{RESULTS}

\section{Patients' characteristics}

One-hundred and eleven pediatric patients (1 month-18 years) with refractory ARDS were supported by ECMO over the 11-year study period. Among them, 25 (22\%) were immunocompromised. Four patients suffered from having a solid tumor, one patient had a bone marrow transplant for sickle cell disease, one patient had a congenital immunodeficiency syndrome, two patients had solid organ transplantation, and seventeen patients suffered from acute lymphoblastic leukemia (Figure I). There was no statistical difference regarding demographic characteristics between the two groups of patients (Table I). PIM II score was 
significantly higher in immunocompromised patients compared to immunocompetent ones $(23 \pm 22$ versus $13.5 \pm 18.7 ; \mathrm{p}=0.02)$. Oxygenation features $\left(\mathrm{PaO}_{2} / \mathrm{FiO}_{2}\right.$ ratio, Oxygenation Saturation Index (OSI) and Oxygenation Index (OI)) were not significantly different between the two groups. ARDS main etiology was pneumonia in both groups. Fungal infection frequency was significantly higher in the immunocompromised patients $(12.5 \%$ versus $0 \%$ in the control group; $\mathrm{p}=0.001)$.

\section{Pre-ECMO clinical and lab characteristics}

There was no significant difference, either in blood gas values, or in ventilator settings, including tidal volume and positive end expiratory pressure (Table II). Significantly higher fluid resuscitation volumes were used non-immunocompromised patients compared to the immunocompromised group, respectively $65 \pm 46 \mathrm{ml} / \mathrm{kg}$ versus $25 \pm 19 \mathrm{ml} / \mathrm{kg}(\mathrm{p}=0.05)$. No significant difference was found in the blood cells count of immunocompromised patients compared to the non-immunocompromised group.

\section{Patient outcomes}

ECMO weaning rate was significantly higher in the non-immunocompromised group compared to immunocompromised patients (73\% versus 52\%; p : 0.0005 ). Survival rate 6 months after ICU discharge was significantly lower in immunocompromised patients than in the control group $(41.7 \%$ versus $62.8 \% ; \mathrm{p}=0.04)$. The decision to withdraw life-sustaining measures was significantly more frequent for immunocompromised patients $33.3 \%$ versus $8.4 \% ; \mathrm{p}=0.001)$. There was no significant difference in length of hospitalization, length of ECMO or mechanical ventilation settings between immunocompromised children and the non-immunocompromised group. We observed that immunocompromised children experienced more frequently multi-organ failure than non-immunocompromised ones (Table III). 


\section{Intensive Care and ECMO-related complications}

Nasopharyngeal, gastro-intestinal and urogenital hemorrhage occurred significantly more often in immunocompromised group, respectively $50 \%$ vs $13,5 \%(\mathrm{p}=0.001), 37.5 \%$ vs 9.6\% ( $p=0.003)$ and $16.7 \%$ vs $3.6 \%(p=0.004)$. No significant difference between the groups was found for ventilator-acquired pneumonia or central line associated bloodstream infection (Table IV).

\section{DISCUSSION}

Our report is the first French study, and one of the largest studies regarding ECMO, studying pediatric ARDS (P-ARDS) in immunocompromised patients. As expected, children with immunodeficiency had a lower survival rate than immunocompetent patients $(41,7 \%$ versus $62.8 \%$ ). We found a survival rate six month after PICU discharge of $41 \%$ in the immunocompromised population, which is higher than previously reported by Zabrocki et al. $(30-34 \%)^{(4)}$, Gupta et al. $(31 \%)^{(17)}$ and Gow et al. (35\%) in pediatric population ${ }^{(18)}$ and $32 \%$ in adult patients ${ }^{(19)}$. This gap can be explained by the continuous improvement of materials used for ECMO. Moreover, we use in our unit a lung protocol aiming at tidily control ventilatory pressure during ECMO. Moreover, a multidisciplinary evaluation is made before every ECMO implantation in an immunocompromised patient. Finally, due to the low reported survival rate ${ }^{(11)}$, we actually do not use ECMO for refractory ARDS in a patient after a bone marrow transplantation. Gow et al. reported $42 \%$ who survived to ECLS runs in children immunocompromised population ${ }^{(18)}$ and $39 \%$ in adult immunocompromised population ${ }^{(19)}$, which is consistent with our findings. These results corroborate that survival is lower for immunocompromised children respiratory supported by ECMO compared to overall survival in extracorporeal life supported pediatric patients across all categories. The latter is 
being reported around $60 \%$ this past 25 years according to the Extracorporeal Life Support Organization (ELSO) registry report ${ }^{(5)}$. However, this survival rate appears reasonable relative to pediatric Extracorporeal Cardiopulmonary Resuscitation (ECPR) survival rate of $42 \%$ reported by ELSO ${ }^{(5)}$ or lower reported by Wolf et al. ${ }^{(20)}$, or in cases of pediatric ECLS provided for respiratory failure due to pertussis $(32 \%)^{(5,21,22)}$.

Another major result of our study is the etiology of the P-ARDS; all fungal pneumonia occurred in an already known immunodeficiency or revealed this severe pathology. It seems to us that all P-ARDS in a supposed immunocompetent child should lead to specific immunodeficiency research. Furthermore, all P-ARDS in immunocompromised patients might benefit from probabilistic anti-fungal therapy.

P-ARDS severity did not seem to explain the higher mortality rate in immunocompromised group. Indeed, there was no difference between the two groups, either in $\mathrm{PaO}_{2} / \mathrm{FiO}_{2}$ ratio, or in OI or OSI (according to PALICC severity stratification). In a secondary analysis of the Large observational study to Understand the Global Impact of Severe Acute respiratory Failure (LUNG SAFE) study ${ }^{(23)}$ database, Cortegiani et al. ${ }^{(6)}$ found similar ARDS severity, according to the Berlin definition criteria, between immunocompromised and non-immunocompromised adult patients treated with conventional management for ARDS. It should be noted that PIM II score ${ }^{(14)}$ was significantly higher in the immunocompromised population.

Contrary to Bailly et al. ${ }^{(24)}$ and Zabrocki et al. ${ }^{(4)}$, there was no significant difference among the clinical or biological data gathered prior to ECMO between the two groups. As a consequence of this findings associated with the expected survival rate, it seems to us that it could be useful to consider ECMO for P-ARDS in all immunocompromised children even if 
severe congenital immune deficiency and bone marrow transplantation remain challenging pathologies to implant ${ }^{(11,25)}$.

However, ECMO use in immunocompromised children is associated with more ECMO-related complications. We reported in our study a higher rate of bleeding complications, especially for nasopharyngeal, gastrointestinal and urogenital hemorrhage, in the immunocompromised group compared to the control group. Moreover, bleeding complications are already known to be associated with a higher mortality rate. Dalton et al. reported that bleeding events occurring in neonatal and pediatric patients during ECMO runs were independently associated with a higher risk of death ${ }^{(26,27)}$. Besides, Schmidt et al. ${ }^{(12)}$ showed that major bleeding related to ECMO was associated with higher mortality in adult immunocompromised patients supported with ECMO for severe ARDS. Due to this higher risk of hemorrhage, in addition to the potential risk of anemia and/or thrombocytopenia secondary to their underlying disease or treatments, immunocompromised children supported with ECMO significantly needed more blood products transfusions. Smith et al. reported red cell transfusion as an independent predictor of mortality among patients undergoing ECMO for respiratory failure. Also, platelets consumption was significantly higher among nonsurvivors compared to survivors ${ }^{(28)}$. Red bloods cells and platelets consumption is strongly linked to a higher cost of care.

Surprisingly, we did not observe any significant difference between groups regarding nosocomial infections. These results are consistent with previous adults' studies ${ }^{(12,29)}$ which have reported that the occurrence of any ECMO-related infections was not associated with increased mortality.

Our study has several limitations that need to be considered. For a start, the data are limited because of retrospective collection. Also, ECMO techniques and general management 
of PARDS have gradually evolved over the past ten years. Because it is a single experienced ECMO center observational study, the limited number of patients and their heterogeneity may have weakened the statistical power of the study and the generalizability of our results may be limited. Despite the wild range of age and the small number of patients, our data are supported by recent publications ${ }^{(30)}$.

\section{CONCLUSION}

Survival rate of immunocompromised children supported with ECMO for P-ARDS is lower than non-immunocompromised children, but the expectation for a great outcome is real and it is worth it if their condition is likely to be compatible with a good long-term quality of life. ECMO support will remain one of the most challenging decisions for the clinician and each case should be evaluated in a multidisciplinary meeting before implementation.

\section{AUTHORS SECTION AREA}

All authors read and approved the final version of the manuscript

BR collected the data, wrote the manuscript

IG performed the statistical analysis

JJ, SJ, YS, JEP and PLL reviewed the manuscript

JS reviewed and proofread the manuscript to assure an English translation

JR proposed the concept, wrote, reviewed, and performed some analysis of the manuscript. 


\section{REFERENCES}

1. Wong JJ-M, Phan HP, Phumeetham S, Ong JSM, Chor YK, Qian S, et al. Risk Stratification in Pediatric Acute Respiratory Distress Syndrome: A Multicenter Observational Study. Crit Care Med. 2017;45(11):1820- 8.

2. Khemani RG, Smith L, Lopez-Fernandez YM, Kwok J, Morzov R, Klein MJ, et al. Paediatric acute respiratory distress syndrome incidence and epidemiology (PARDIE): an international, observational study. Lancet Respir Med. 2018;7(2):115- 28.

3. The Pediatric Acute Lung Injury Consensus Conference Group. Pediatric Acute Respiratory Distress Syndrome: Consensus Recommendations From the Pediatric Acute Lung Injury Consensus Conference*. Pediatric Critical Care Medicine. 2015;16(5):428- 39 .

4. Zabrocki LA, Brogan TV, Statler KD, Poss WB, Rollins MD, Bratton SL. Extracorporeal membrane oxygenation for pediatric respiratory failure: Survival and predictors of mortality. Crit Care Med. 2011;39(2):364- 70.

5. Barbaro RP, Paden ML, Guner YS, Raman L, Ryerson LM, Alexander P, et al. Pediatric Extracorporeal Life Support Organization Registry International Report 2016. ASAIO J. 2017;63(4):456- 63.

6. Cortegiani A, Madotto F, Gregoretti C, Bellani G, Laffey JG, Pham T, et al. Immunocompromised patients with acute respiratory distress syndrome: secondary analysis of the LUNG SAFE database. Crit Care. 2018;22(1):157.

7. Fuchs H, Rossmann N, Schmid MB, Hoenig M, Thome U, Mayer B, et al. Permissive hypercapnia for severe acute respiratory distress syndrome in immunocompromised children: A single center experience. PLoS ONE. 2017;12(6):e0179974. 
8. Erickson S, Schibler A, Numa A, Nuthall G, Yung M, Pascoe E, et al. Acute lung injury in pediatric intensive care in Australia and New Zealand: a prospective, multicenter, observational study. Pediatr Crit Care Med. 2007;8(4):317- 23.

9. Schouten LRA, Veltkamp F, Bos AP, van Woensel JBM, Serpa Neto A, Schultz MJ, et al. Incidence and Mortality of Acute Respiratory Distress Syndrome in Children: A Systematic Review and Meta-Analysis. Crit Care Med. 2016;44(4):819- 29.

10. Spicer AC, Calfee CS, Zinter MS, Khemani RG, Lo VP, Alkhouli MF, et al. A Simple and Robust Bedside Model for Mortality Risk in Pediatric Patients With Acute Respiratory Distress Syndrome. Pediatr Crit Care Med. 2016;17(10):907- 16.

11. Wohlfarth P, Beutel G, Lebiedz P, Stemmler H-J, Staudinger T, Schmidt M, et al. Characteristics and Outcome of Patients After Allogeneic Hematopoietic Stem Cell Transplantation Treated With Extracorporeal Membrane Oxygenation for Acute Respiratory Distress Syndrome. Crit Care Med. 2017;45(5):e500- 7.

12. Schmidt M, Schellongowski P, Patroniti N, Taccone FS, Reis Miranda D, Reuter J, et al. Six-month Outcome of Immunocompromised Severe ARDS Patients Rescued by ECMO. An International Multicenter Retrospective Study. Am J Respir Crit Care Med. 2018;

13. Schmidt M, Franchineau G, Combes A. Recent advances in venovenous extracorporeal membrane oxygenation for severe acute respiratory distress syndrome. Curr Opin Crit Care. 2019;25(1):71- 6 .

14. Slater A, Shann F, Pearson G, Paediatric Index of Mortality (PIM) Study Group. PIM2: a revised version of the Paediatric Index of Mortality. Intensive Care Med. 2003;29(2):278- 85 .

15. Leteurtre S, Martinot A, Duhamel A, Proulx F, Grandbastien B, Cotting J, et al. Validation of the paediatric logistic organ dysfunction (PELOD) score: prospective, observational, multicentre study. Lancet. 2003;362(9379):192- 7.

16. McIntosh AM, Tong S, Deakyne SJ, Davidson JA, Scott HF. Validation of the Vasoactive-Inotropic Score in Pediatric Sepsis. Pediatr Crit Care Med. 2017;18(8):750- 7.

17. Gupta M, Shanley TP, Moler FW. Extracorporeal life support for severe respiratory failure in children with immune compromised conditions. Pediatr Crit Care Med. 2008;9(4):380 - 5 .

18. Gow KW, Heiss KF, Wulkan ML, Katzenstein HM, Rosenberg ES, Heard ML, et al. Extracorporeal life support for support of children with malignancy and respiratory or cardiac failure: The extracorporeal life support experience*: Critical Care Medicine. 2009;37(4):1308- 16.

19. Gow KW, Lao OB, Leong T, Fortenberry JD. Extracorporeal life support for adults with malignancy and respiratory or cardiac failure: The Extracorporeal Life Support experience. Am J Surg. 2010;199(5):669- 75. 
20. Wolf MJ, Kanter KR, Kirshbom PM, Kogon BE, Wagoner SF. Extracorporeal cardiopulmonary resuscitation for pediatric cardiac patients. Ann Thorac Surg. 2012;94(3):874- 9; discussion 879-880.

21. Domico M, Ridout D, MacLaren G, Barbaro R, Annich G, Schlapbach LJ, et al. Extracorporeal Membrane Oxygenation for Pertussis: Predictors of Outcome Including Pulmonary Hypertension and Leukodepletion. Pediatr Crit Care Med. 2018;19(3):254- 61.

22. Straney L, Schibler A, Ganeshalingham A, Alexander J, Festa M, Slater A, et al. Burden and Outcomes of Severe Pertussis Infection in Critically Ill Infants. Pediatr Crit Care Med. 2016;17(8):735- 42.

23. Bellani G, Laffey JG, Pham T, Fan E, Brochard L, Esteban A, et al. Epidemiology, Patterns of Care, and Mortality for Patients With Acute Respiratory Distress Syndrome in Intensive Care Units in 50 Countries. JAMA. 2016;315(8):788- 800.

24. Bailly DK, Reeder RW, Zabrocki LA, Hubbard AM, Wilkes J, Bratton SL, et al. Development and Validation of a Score to Predict Mortality in Children Undergoing Extracorporeal Membrane Oxygenation for Respiratory Failure: Pediatric Pulmonary Rescue With Extracorporeal Membrane Oxygenation Prediction Score*. Critical Care Medicine. 2017;45(1):e58- 66.

25. Schmidt M, Combes A, Shekar K. ECMO for immunosuppressed patients with acute respiratory distress syndrome: drawing a line in the sand. Intensive Care Med. 2019;

26. Dalton HJ, Garcia-Filion P, Holubkov R, Moler FW, Shanley T, Heidemann S, et al. Association of bleeding and thrombosis with outcome in extracorporeal life support. Pediatr Crit Care Med. 2015;16(2):167- 74.

27. Dalton HJ, Reeder R, Garcia-Filion P, Holubkov R, Berg RA, Zuppa A, et al. Factors Associated with Bleeding and Thrombosis in Children Receiving Extracorporeal Membrane Oxygenation. Am J Respir Crit Care Med. 2017;196(6):762- 71.

28. Smith A, Hardison D, Bridges B, Pietsch J. Red blood cell transfusion volume and mortality among patients receiving extracorporeal membrane oxygenation. Perfusion. 2013;28(1):54- 60 .

29. Biffi S, Di Bella S, Scaravilli V, Peri AM, Grasselli G, Alagna L, et al. Infections during extracorporeal membrane oxygenation: epidemiology, risk factors, pathogenesis and prevention. Int J Antimicrob Agents. 2017;50(1):9- 16.

30. Ranta S, Kalzén H, Nilsson A, von Schewelov K, Broman LM, Berner J, et al. Extracorporeal Membrane Oxygenation Support in Children With Hematological Malignancies in Sweden. J Pediatr Hematol Oncol. 2020; 



\section{Figure caption}

Figure I : Flow chart

\begin{tabular}{|c|c|c|c|}
\hline Demographic datas & $\begin{array}{l}\text { Non- Immunocompromised } \\
\qquad(\mathrm{N}: 86)\end{array}$ & $\begin{array}{c}\text { Immunocompromised } \\
(\mathrm{N}: 25)\end{array}$ & $\mathrm{p}$ value \\
\hline \multicolumn{4}{|l|}{ Demographic characteristics } \\
\hline Age (days) & $872 \pm 1286$ & $1366 \pm 1492$ & NS \\
\hline Weight $(\mathrm{kg})$, mean $\pm \mathrm{SD}$ & $11.6 \pm 12.7$ & $15.9 \pm 17.7$ & NS \\
\hline Gender, male, n (\%) & 54.6 & 60.0 & NS \\
\hline \multicolumn{4}{|l|}{ Pre-ECMO severity scores } \\
\hline AaDO2 Score & $565 \pm 49$ & $555 \pm 46$ & NS \\
\hline Oxygenation index & $40 \pm 18$ & $35 \pm 12$ & NS \\
\hline Oxygenation saturation index & $24 \pm 10$ & $25 \pm 8$ & NS \\
\hline PELOD score $(\%)$ & $17 \pm 23$ & $15 \pm 25$ & NS \\
\hline $\mathrm{PaO}_{2} / \mathrm{FiO}_{2}$ ratio & $63 \pm 31$ & $71 \pm 35$ & NS \\
\hline PIM II score $(\%)$ & $13.5 \pm 18.7$ & $23 \pm 22$ & 0.02 \\
\hline $\mathrm{SpO}_{2} / \mathrm{FiO}_{2}$ ratio & $86 \pm 22$ & $92 \pm 25$ & $\mathrm{NS}$ \\
\hline \multicolumn{4}{|l|}{ ARDS etiology } \\
\hline Status asthmaticus (\%) & 3.6 & 0 & NS \\
\hline Pneumonia $(\%)$ & 80.1 & 64.2 & NS \\
\hline Bacterial infection $(\%)$ & 51.8 & 25.1 & 0.02 \\
\hline Fungal infection (\%) & 0 & 12.5 & 0.001 \\
\hline Viral infection $(\%)$ & 54.9 & 33.3 & NS \\
\hline
\end{tabular}

Table I : Patients characteristics 


\begin{tabular}{|c|c|c|c|}
\hline Findings prior to ECMO & $\begin{array}{c}\text { Non- } \\
\text { Immunocompromised } \\
(\mathrm{N}: 86)\end{array}$ & $\begin{array}{c}\text { Immunocompromised } \\
(\mathrm{N}: 25)\end{array}$ & $\begin{array}{c}\mathrm{p} \\
\text { value }\end{array}$ \\
\hline \multicolumn{4}{|l|}{ Hemodynamic data's } \\
\hline Cardiac output $\left(1 / \mathrm{m}_{2} / \mathrm{min}\right)$ & $3.3 \pm 1.9$ & $3.4 \pm 1.5$ & NS \\
\hline Fluid resuscitation $(\mathrm{ml} / \mathrm{kg})$ & $65 \pm 46$ & $25 \pm 19$ & 0.05 \\
\hline Vasoactive score $(\mu \mathrm{g} / \mathrm{kg} / \mathrm{min})$ & $49 \pm 60$ & $50 \pm 101$ & NS \\
\hline $\operatorname{LVEF}(\%)$ & $66 \pm 9$ & $52 \pm 20$ & NS \\
\hline Lactate $(\mathrm{mmol} / \mathrm{l})$ & $2.5 \pm 2.8$ & $3.6 \pm 4.7$ & NS \\
\hline \multicolumn{4}{|l|}{ Respiratory data's } \\
\hline $\begin{array}{l}\text { Pre ECMO length of invasive } \\
\text { ventilation (days) }\end{array}$ & $4.6 \pm 3.9$ & $3.7 \pm 3.2$ & NS \\
\hline Inspiratory pressure $\left(\mathrm{cmH}_{2} \mathrm{O}\right)$ & $46 \pm 13$ & $42 \pm 8$ & NS \\
\hline Tidal volume $(\mathrm{ml} / \mathrm{kg})$ & $6.8 \pm 1.7$ & $6.2 \pm 1.3$ & NS \\
\hline Plateau pressure $\left(\mathrm{cmH}_{2} \mathrm{O}\right)$ & $37.1 \pm 8.3$ & $35.7 \pm 5.7$ & NS \\
\hline Driving pressure $\left(\mathrm{cmH}_{2} \mathrm{O}\right)$ & $27 \pm 9$ & $24 \pm 6$ & NS \\
\hline $\begin{array}{l}\text { Positive end expiratory } \\
\text { pressure }\left(\mathrm{cmH}_{2} \mathrm{O}\right)\end{array}$ & $10.1 \pm 4.1$ & $10.8 \pm 3.1$ & NS \\
\hline $\begin{array}{l}\text { Mean airway pressure } \\
\left(\mathrm{cmH}_{2} \mathrm{O}\right)\end{array}$ & $20.4 \pm 6.3$ & $21 \pm 3.3$ & NS \\
\hline $\begin{array}{l}\text { Inspired fraction of oxygen } \\
(\%)\end{array}$ & $98 \pm 7$ & $98 \pm 7$ & NS \\
\hline $\mathrm{PaO}_{2}(\mathrm{mmHg})$ & $58 \pm 23$ & $62 \pm 18$ & NS \\
\hline $\mathrm{PaCO}_{2}(\mathrm{mmHg})$ & $66 \pm 25$ & $71 \pm 27$ & NS \\
\hline $\mathrm{pH}$ & $7.2 \pm 0.2$ & $7.2 \pm 0.2$ & NS \\
\hline Neuromuscular blockers (\%) & 98.8 & 96.1 & NS \\
\hline Prone positioning $(\%)$ & 42.8 & 44.1 & NS \\
\hline \multicolumn{4}{|l|}{ Metabolic data's } \\
\hline $\mathrm{CRP}(\mathrm{mg} / \mathrm{l})$ & $120 \pm 108$ & $113 \pm 101$ & NS \\
\hline Serum creatinine $(\mu \mathrm{mol} / \mathrm{l})$ & $36 \pm 35$ & $44 \pm 42$ & NS \\
\hline
\end{tabular}




\begin{tabular}{|l|c|c|c|}
\hline $\begin{array}{l}\text { Schwartz clearance } \\
(\mu \mathrm{mol} / \mathrm{ml} / \mathrm{min})\end{array}$ & $124 \pm 79$ & $136 \pm 69$ & NS \\
\hline Urine output $(\mathrm{ml} / \mathrm{kg} / \mathrm{h})$ & $3.3 \pm 2.5$ & $3.1 \pm 2.5$ & NS \\
\hline \multicolumn{1}{|c|}{ Hematologic data's } & & & \\
\hline Hemoglobin $(\mathrm{g} / \mathrm{dl})$ & $10.5 \pm 1.9$ & $10.4 \pm 1.9$ & NS \\
\hline White blood cells $\left(/ \mathrm{mm}_{3}\right)$ & $16153 \pm 9615$ & $12879 \pm 10648$ & NS \\
\hline Lymphocytes $\left(/ \mathrm{mm}_{3}\right)$ & $2565 \pm 3325$ & $1030 \pm 1120$ & NS \\
\hline Neutrophils count $\left(/ \mathrm{mm}_{3}\right)$ & $7805 \pm 6370$ & $8045 \pm 8633$ & NS \\
\hline Platelets $\left(/ \mathrm{mm}_{3}\right)$ & $232083 \pm 152782$ & $160120 \pm 132534$ & NS \\
\hline
\end{tabular}

Table II : Clinical and Biological findings prior to ECMO

LVEF: Left Ventricular Ejection Fraction; $\mathrm{PaO}_{2}$ : Partial pressure of arterial Oxygen; $\mathrm{PaCO}_{2}$ : Carbon dioxide partial pressure; CRP : C-Reactive Protein 


\begin{tabular}{|l|c|c|c|}
\hline \multicolumn{1}{|c|}{ Outcomes } & $\begin{array}{c}\text { Non- } \\
\text { Immunocompromised } \\
(\mathrm{N}: 86)\end{array}$ & $\begin{array}{c}\text { Immunocompromised } \\
(\mathrm{N}: 25)\end{array}$ & $\mathrm{p}$ value \\
\hline Fibrinogen concentrate (unit) & $0.4 \pm 1.2$ & $0.1 \pm 0.3$ & $\mathrm{NS}$ \\
\hline Platelet consumption (unit) & $4.8 \pm 7.8$ & $12.1 \pm 15.1$ & 0.002 \\
\hline Red blood cell consumption (unit) & $2.9 \pm 3.5$ & $4.8 \pm 4.5$ & 0.04 \\
\hline AT III consumption (unit) & $0.9 \pm 1.6$ & $0.9 \pm 1.9$ & $\mathrm{NS}$ \\
\hline Fresh frozen plasma concentrate (unit) & $0.8 \pm 1.9$ & $0.6 \pm 1.1$ & $\mathrm{NS}$ \\
\hline Length of ECMO (days) & $11.2 \pm 10.8$ & $13.3 \pm 10.1$ & $\mathrm{NS}$ \\
\hline $\begin{array}{l}\text { Length of invasive mechanical ventilation } \\
\text { (days) }\end{array}$ & $24.7 \pm 21.3$ & $17.9 \pm 13.2$ & $\mathrm{NS}$ \\
\hline Length of vasoactive support (days) & & & $\mathrm{NS}$ \\
\hline ECMO weaning rate (\%) & $5.9 \pm 5.5$ & $6.8 \pm 8.3$ & 0.0005 \\
\hline Intensive care discharge rate (\%) & 73 & 52 & $\mathrm{NS}$ \\
\hline Survival rate at 6 months (\%) & 64 & 44 & 0.004 \\
\hline Palliative care (\%) & 8.4 & 41.7 & 0.001 \\
\hline Multi-organ failure (\%) & 12.1 & 33.3 & 0.05 \\
\hline
\end{tabular}

Table III: Clinical and biological endpoints

AT III = Antithrombin III 


\begin{tabular}{|l|c|c|c|}
\hline \multicolumn{1}{|c|}{ Complications } & $\begin{array}{c}\text { Non- Immunocompromised } \\
(\mathrm{N}: 86)\end{array}$ & $\begin{array}{c}\text { Immunocompromised } \\
(\mathrm{N}: 25)\end{array}$ & $\mathrm{p}$ value \\
\hline Fluid overload at weaning (\%) & $8.2 \pm 6.1$ & $8.9 \pm 6.1$ & $\mathrm{NS}$ \\
\hline Renal replacement therapy (\%) & 4.3 & 6.5 & NS \\
\hline Ischemic Stroke (\%) & 4.8 & 0 & NS \\
\hline Cerebral hemorrhage (\%) & 6.1 & 8.3 & NS \\
\hline Cannula hemorrhage (\%) & 24.4 & 45.8 & NS \\
\hline Gastro-intestinal hemorrhage (\%) & 9.6 & 37.5 & 0.003 \\
\hline Nasopharyngeal hemorrhage (\%) & 13.3 & 50.1 & 0.001 \\
\hline Pulmonary hemorrhage (\%) & 8.5 & 20.8 & NS \\
\hline Urogenital hemorrhage (\%) & 3.6 & 16.7 & 0.04 \\
\hline Central line associated bloodstream infection (\%) & 10.8 & 12.5 & NS \\
\hline Ventilator associated pneumonia (\%) & 21.7 & 25.1 & NS \\
\hline
\end{tabular}

Table IV : Intensive Care and ECMO-related complications 